\title{
Ferrimonas marina sp. nov.
}

Correspondence
Hiroaki Kasai
hiroaki.kasai@mbio.jp

\author{
Atsuko Katsuta, Kyoko Adachi, Satoru Matsuda, Yoshikazu Shizuri \\ and Hiroaki Kasai
}

Marine Biotechnology Institute, 3-75-1 Heita, Kamaishi, Iwate 026-0001, Japan

\begin{abstract}
A novel Ferrimonas species is described on the basis of phenotypic, chemotaxonomic and phylogenetic studies. Four halophilic organisms were isolated from marine sand and marine macroalgae samples by using high-pH marine agar 2216. An analysis of the nearly complete $16 \mathrm{~S}$ rRNA gene sequences of these new isolates indicated that they were phylogenetically close (16S rRNA gene sequence similarity $>99 \cdot 5 \%$, gyrB gene sequence similarity $>97 \cdot 8 \%$ ), and were most closely related to Ferrimonas balearica (16S rRNA gene sequence similarity 97·1-97.3\%, gyrB gene sequence similarity 84·4-85.0\%). Chemotaxonomic data (major menaquinone MK7; major fatty acids $C_{16: 0}$ and $\left.C_{18: 1} \omega 9 c\right)$ supported the affiliation of the new isolates to the genus Ferrimonas. The results of physiological and biochemical tests allowed phenotypic differentiation of the isolates from F. balearica. It is therefore proposed that the new isolates represent a novel species with the name Ferrimonas marina sp. nov. and type strain A4D-4 ${ }^{\top}\left(=\right.$ MBIC06480 ${ }^{\top}=$ DSM $\left.16917^{\top}\right)$.
\end{abstract}

A study applying the polyphasic approach to microbial taxonomy was conducted on strains isolated from marine sand, algae and animal samples taken from tropical waters off the Republic of Palau and Japan in 2002, 2003 and 2004. The strains were isolated by using marine agar 2216 (MA; Difco) with the $\mathrm{pH}$ adjusted to 11 with $\mathrm{Na}_{2} \mathrm{CO}_{3}$ and $\mathrm{NaHCO}_{3}$. Beige-coloured colonies were isolated and purified on $\mathrm{pH} 11 \mathrm{MA}$, and nine of these were designated strains A2A-18, A2A-30, A3B-8, A3B-47-3, A3B-57-2, A3B$58, \mathrm{~A} 3 \mathrm{~B}-59, \mathrm{~A} 3 \mathrm{~B}-64-2$ and $\mathrm{A} 4 \mathrm{D}-\mathrm{4}^{\mathrm{T}}$ (further strain information is given in Supplementary Table S1 available in IJSEM Online). These strains were maintained in $10 \%$ glycerol at $-80^{\circ} \mathrm{C}$ and preserved by the L-dry method (Sakane \& Kuroshima, 1997).

Chromosomal DNA was purified from the above nine strains by using the Genomic-tip and buffer set (Qiagen). The 16S rRNA gene fragment was amplified by using universal primers corresponding to positions $8-27$ as the forward primer and 1492-1510 as the reverse primer (Escherichia coli numbering system; Weisburg et al., 1991).

Published online ahead of print on 6 May 2005 as DOI 10.1099/ ijs.0.63689-0.

\footnotetext{
Abbreviation: $\mathrm{NJ}$, neighbour-joining.

The GenBank/EMBL/DDBJ accession numbers for the 16S rRNA gene sequences of the strains examined here are AB193748AB193756, and those for the gyrB gene sequences are AB193757AB193766.
}

Details of the strains isolated in this study are given in a supplementary table in IJSEM Online.
The $1460 \mathrm{bp}$ nucleotide sequences thus determined were used to search for phylogenetically related bacteria. The $16 \mathrm{~S}$ rRNA gene sequences were compared with both the bacterial sequence data stored in the DDBJ database by using the BLAST algorithm (Altschul et al., 1990) and the 16S rRNA gene sequence data stored in RDP-II (Cole et al., 2003) by using the Sequence Match tool. Both results suggested that the closest recognized relative was Ferrimonas balearica. The gyrB gene was analysed to differentiate the nine strains, plus the type strain of F. balearica, DSM $9799^{\mathrm{T}}$. The gyrB gene fragment covering positions $274-1525$ in the E. coli gyrB gene was amplified by using the deoxyinosinecontaining primers UP1Ei (5'-GAAGTCATCACCGTTCTGCAYGSIGGIGGIAARTTYRA-3') and UP2ri (5'-AGCAGGGTACGGATGTGCGAGCCRTCIACRTCIGCRTCIGTCAT- $3^{\prime}$ ). The PCR products were purified by using a Suprec-02 cartridge (Takara Biochemicals). Sequencing was performed by using primers UP1s ( $5^{\prime}$-GAAGTCATCACCGTTCTGCA- $3^{\prime}$ ) and UP2rs (5'-AGCAGGGTACGGATGTGCGAGCC-3') as described by Yamamoto \& Harayama (1995).

The $1460 \mathrm{bp}$ nucleotide sequences of the $16 \mathrm{~S}$ rRNA gene and 1170 bp gyrB gene sequences were used for a phylogenetic analysis. This analysis was performed by using the TREECON (Van de Peer \& De Wachter, 1994) and MEGA2 (Kumar et al., 2001) software packages after multiple alignment of the data by CLUSTAL X (Thompson et al., 1997). Distances (distance options according to the Kimura twoparameter model) and clustering by the neighbour-joining $(\mathrm{NJ})$ and maximum-parsimony methods were determined by using bootstrap values based on 1000 replications. 
Alignment gaps and unidentified base positions were not taken into consideration for the calculations.

Phylogenetic trees constructed by using the NJ method based on $16 \mathrm{~S}$ rRNA and gyrB gene sequence data are shown in Fig. 1. The ten strains were clustered into two groups based on both genes with a high bootstrap value (100\%). One group includes strains A2A-18, A3B-47-3, A3B-58, A3B-57-2 and the type strain of F. balearica DSM $9799^{\mathrm{T}}$, and the second group includes A2A-30, A3B-8, A3B-59, A3B-642 and $\mathrm{A} 4 \mathrm{D}-4^{\mathrm{T}}$. The number of nucleotide substitutions in each group for the 16S rRNA gene varied from 2 to 24 , with a mean sequence similarity of greater than $98.4 \%$, whereas the nucleotide substitutions between strains in the two groups varied from 33 to 43 , with a mean sequence similarity of less than $97 \cdot 7 \%$. For the $\operatorname{gyrB}$ gene, the number of nucleotide substitutions in each group varied from 6 to 57, with a mean sequence similarity of greater than $95.1 \%$, whereas the number of nucleotide substitutions between strains in the two groups varied from 176 to 198 , with a mean sequence similarity of less than $85.0 \%$. These values represent sufficient sequence diversity to imply distinct species (Satomi et al., 2003).

A DNA-DNA hybridization experiment was performed to determine relatedness between F. balearica DSM $9799^{\mathrm{T}}$ and the other strains, and between strain $\mathrm{A} 4 \mathrm{D}-4^{\mathrm{T}}$ and the other strains. This experiment was conducted by the microplate hybridization method (Ezaki et al., 1989) with Photoprobe ${ }^{\circledR}$ biotin (Vector)-labelled probes under optimal conditions $(2 \times$ SSC and $50 \%$ formamide at $50{ }^{\circ} \mathrm{C}$ ). A colorimetric detection method was applied, using ABTS diammonium salt (Wako) as the substrate and the streptavidin-horseradish peroxidase conjugate (Gibco-BRL) as the colorimetric enzyme. The DNA-DNA hybridization results indicate that seven strains, including F. balearica DSM $9799^{\mathrm{T}}$, could be divided into two groups, I and II, with hybridization values of greater than $65 \%$. Group I consisted of strains A4D-4 ${ }^{\mathrm{T}}$, A2A-30, A3B-8 and A3B-59, and group II consisted of strains A2A-18, A3B47-3 and F. balearica DSM $9799^{\mathrm{T}}$. Levels of DNA-DNA relatedness for the other three strains, A3B-58, A3B-57-2 (a)
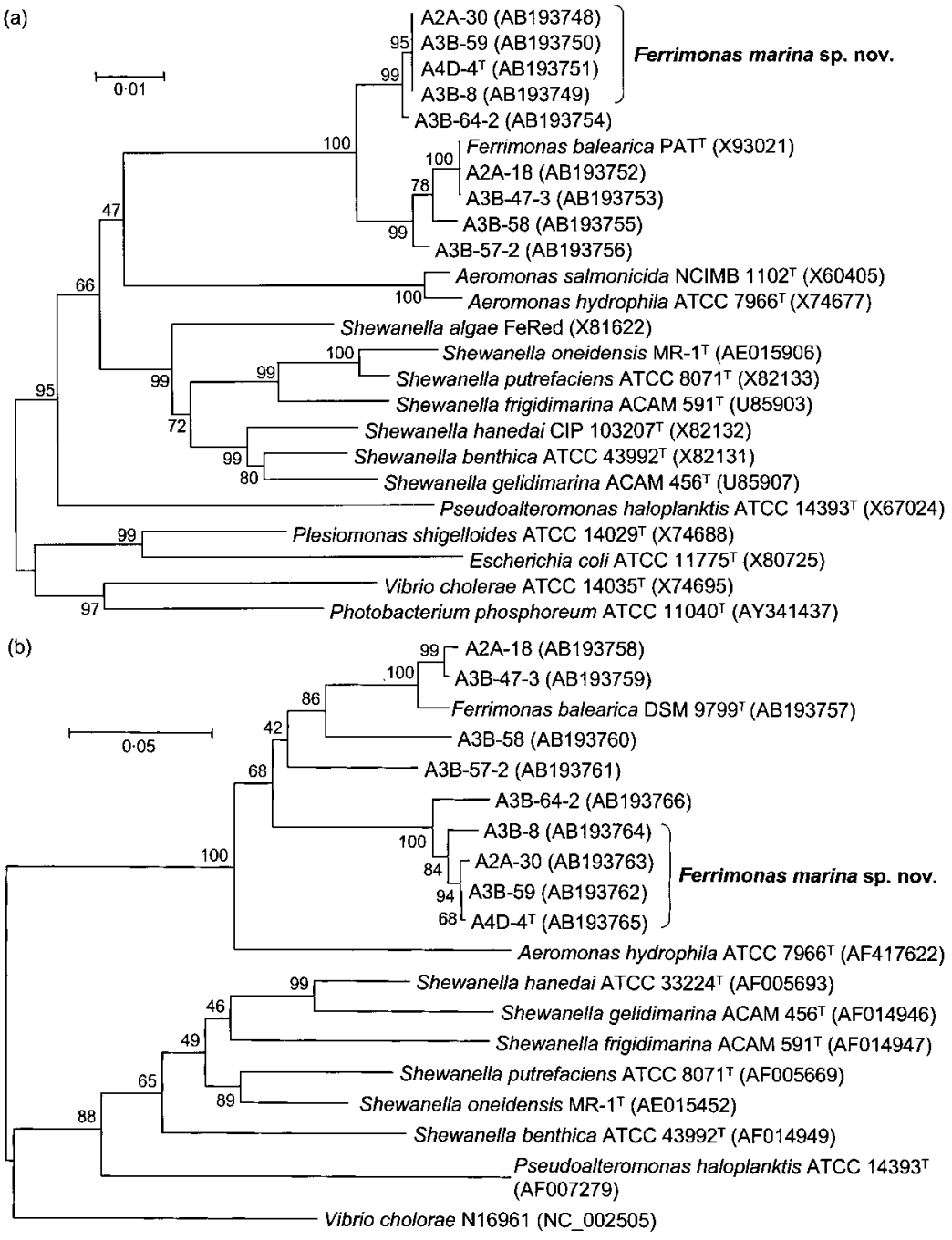

Fig. 1. Phylogenetic trees of the genus Ferrimonas and related taxa based on nucleotide sequences of the 16S rRNA (a) and $\operatorname{gyrB}(\mathrm{b})$ genes. The trees were constructed by using the NJ method and genetic distances were computed by the Kimura two-parameter model. Numbers at nodes indicate the percentage occurrence in 1000 bootstrapped trees. Bars, 0.01 (a) and 0.05 (b) substitutions per nucleotide position. 
and A3B-64-2, against those in groups I and II were less than $10 \%$. The strains classified into group I were subsequently analysed taxonomically using a polyphasic approach in comparison with the strains in group II.

Chemotaxonomic markers were determined in order to identify whether the new isolates were members of the genus Ferrimonas. The cell material used for the chemotaxonomic analysis was obtained from a culture grown in marine broth 2216 (MB; Difco) at $\mathrm{pH} 7 \cdot 6$ for $24 \mathrm{~h}$ at $25^{\circ} \mathrm{C}$ on a rotary shaker. Cells were harvested by centrifugation and washed with artificial sea water. Isoprenoid quinones were analysed by the modified method of Nishijima et al. (1997). Quinones were extracted with chloroform/methanol $(2: 1, \mathrm{v} / \mathrm{v})$ from the freeze-dried cells. After centrifugation, the supernatant was evaporated to dryness and then suspended in acetone. An aliquot of the acetone solution was analysed by an HPLC-atmospheric pressure chemical ionization (APCI)-MS/MS system using a C30 Develosil column (Nomura Chemical). The quinone profile of F. balearica DSM $9799^{\mathrm{T}}$ as determined in this study was as follows: MK7, $62.9 \%$; Q-8, 20.4\%; Q-7, $16 \%$. The isolated strains showed the same types of menaquinone and ubiquinones: A4D-4 ${ }^{\mathrm{T}}$ (MK-7, 52.2\%; Q-7, 25.3\%; Q-8, $17 \%$ ), A2A-30 $(43 \cdot 9,26 \cdot 8,25 \cdot 2 \%)$, A3B- $8(41 \cdot 5,31 \cdot 6,18 \cdot 7 \%)$ and A3B-59 $(44 \cdot 3,29 \cdot 7,21 \cdot 9 \%)$. Cellular fatty acids were extracted from lyophilized cells, methylated and then analysed by using a Shimadzu QP5050A GC/MS instrument. Fatty acid methyl ester (FAME) peaks were identified with BAME Mix (Supelco) by using retention time comparisons against standard compounds. Further identification, including verification of the double-bond position, was performed using the pyrrolidide conversion method (Andersson \& Holman, 1974). The fatty acid compositions are shown in Table 1. Cells grown in $\mathrm{MB}$ at $\mathrm{pH} 7.6$ and $25^{\circ} \mathrm{C}$ for $24 \mathrm{~h}$ were used for the analysis. The fatty acid profile of F. balearica DSM $9799^{\mathrm{T}}$ was different from the published data (RossellóMora, 1995), possibly because the culture medium used was different. The major fatty acids in all isolates and in $F$. balearica cultures, grown in $\mathrm{MB}$ at $\mathrm{pH} 7 \cdot 6$, were $\mathrm{C}_{18: 1} \omega 9 c$, $\mathrm{C}_{16: 0}$ and iso- $\mathrm{C}_{15: 0}$. DNA base compositions were determined by the HPLC method described by Tamaoka \& Komagata (1984); values are shown in Table 2.

The cellular morphology and motility of the novel isolates were observed by phase-contrast microscopy and transmission electron microscopy. Gram-staining was performed as described by Murray et al. (1994). Cells of the new isolates were Gram-negative rods, motile by means of polar flagella. Cells grown for 2 days at $25^{\circ} \mathrm{C}$ on $\mathrm{pH} 7 \cdot 6 \mathrm{MA}$ were $0 \cdot 2$ $0.5 \mu \mathrm{m}$ in diameter and $3.5 \mu \mathrm{m}$ in length. The range of $\mathrm{NaCl}$ concentration for growth was determined on a triple-sugariron (TSI) medium supplemented with $0-10 \% \mathrm{NaCl}$. Two strains (A2A-18 and A3B-47-3) were able to grow at $0 \cdot 5-$ $7 \cdot 5 \% \mathrm{NaCl}$, whereas others (A2A-30, A3B-8, A3B-59 and A $4 \mathrm{D}-4^{\mathrm{T}}$ ) were only able to grow at $1 \cdot 5-3 \cdot 5 \%$ or $5 \cdot 5 \% \mathrm{NaCl}$; the optimal concentration for growth was $3 \cdot 5 \%$. The range of temperature for growth $\left(4,15,20,25,30,37\right.$ and $\left.42{ }^{\circ} \mathrm{C}\right)$ was determined on $\mathrm{pH} 7 \cdot 6 \mathrm{MA}$ for 1 week. All strains except two (A2A-18 and A3B-47-3) were able to grow at $15-37^{\circ} \mathrm{C}$; optimum growth occurred at $25-30^{\circ} \mathrm{C}$. Strains A2A-18 and A3B-47-3 were able to grow at up to $42^{\circ} \mathrm{C}$. The ability to grow at $\mathrm{pH} 5 \cdot 0-11 \cdot 0$ was tested on MA adjusted to various $\mathrm{pH}$ values. All strains grew in the $\mathrm{pH}$ range $6 \cdot 0-11 \cdot 0$. To

Table 1. Fatty acid composition of Ferrimonas species

Strains: 1, A4D-4 ${ }^{\mathrm{T}}$; 2, A2A-30; 3, A3B-8; 4, A3B-59; 5, F. balearica DSM 9799 $;$ 6, A3B-47-3; 7, A2A-18; 8, A3B-58; 9, A3B-57-2; 10, A3B64-2. Only values of $0.99 \%$ or more are listed.

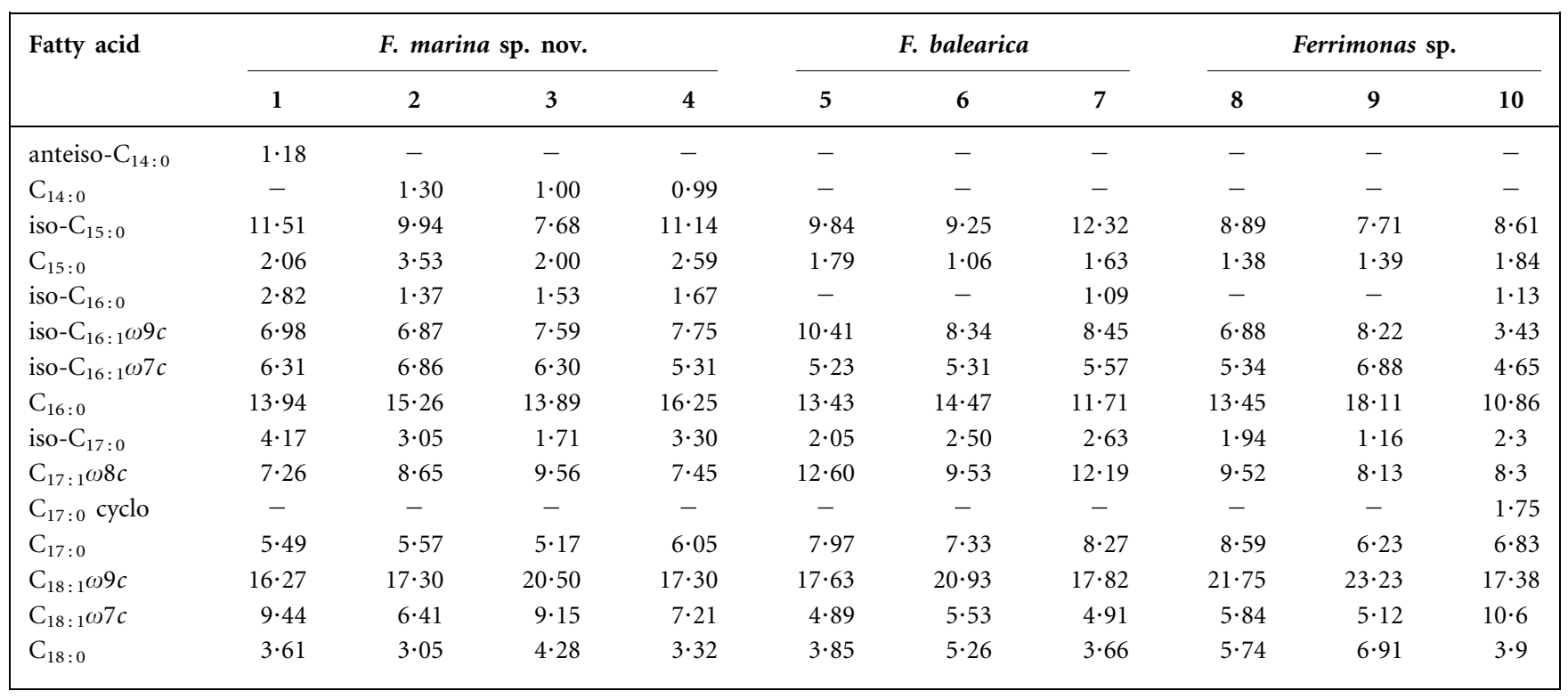


Table 2. Differential characteristics of Ferrimonas species

Strains: 1, A4D-4 ${ }^{\mathrm{T}}$; 2, A2A-30; 3, A3B-8; 4, A3B-59; 5, F. balearica DSM $9799^{\mathrm{T}}$; 6, A2A-18; 7, A3B-47-3. +, Positive; -, negative; $\mathrm{W}+$, weakly positive; ND, not determined; $\mathrm{F}$, fermentative growth in oxidation/fermentation test. Cells of all strains are rods and Gram-negative. All strains are positive for growth at 25 and $37^{\circ} \mathrm{C}$, growth in 1.5 and $3.5 \% \mathrm{NaCl}$, and production of $\mathrm{H}_{2} \mathrm{~S}$ by SIM test.

\begin{tabular}{|c|c|c|c|c|c|c|c|}
\hline \multirow[t]{2}{*}{ Characteristic } & \multicolumn{4}{|c|}{ F. marina sp. nov. } & \multicolumn{3}{|c|}{ F. balearica } \\
\hline & 1 & 2 & 3 & 4 & 5 & 6 & 7 \\
\hline Growth at $42^{\circ} \mathrm{C}$ & - & - & - & - & + & + & + \\
\hline \multicolumn{8}{|l|}{ Growth in $\mathrm{NaCl}$ at (\%): } \\
\hline $0 \cdot 5$ & - & - & - & - & + & + & + \\
\hline $5 \cdot 5$ & - & $\mathrm{w}+$ & - & + & + & + & + \\
\hline \multicolumn{8}{|l|}{ Production of: } \\
\hline $\mathrm{H}_{2} \mathrm{~S}$ (by TSI) & - & - & - & - & + & + & + \\
\hline Urease & - & - & - & - & - & $\mathrm{w}+$ & $\mathrm{w}+$ \\
\hline \multicolumn{8}{|l|}{ Hydrolysis of: } \\
\hline Aesculin & + & + & + & + & - & - & - \\
\hline Casein & - & - & - & - & + & + & + \\
\hline Oxidation/fermentation & $\mathrm{F}$ & $\mathrm{F}$ & $\mathrm{F}$ & $\mathrm{F}$ & ND & $\mathrm{ND}$ & ND \\
\hline $\mathrm{Fe}(\mathrm{III})$ reduction & - & - & - & - & + & + & + \\
\hline \multicolumn{8}{|l|}{ BiOLOG profile: } \\
\hline Dextrin & + & + & + & + & - & ND & ND \\
\hline D-Glucose & + & + & + & + & - & ND & ND \\
\hline Maltose & + & + & + & + & + & ND & ND \\
\hline Acetate & + & + & - & - & + & ND & ND \\
\hline Lactate & + & + & - & + & + & ND & ND \\
\hline L-Alanylglycine & + & + & - & + & - & $\mathrm{ND}$ & ND \\
\hline L-Glutamate & + & + & - & - & + & ND & ND \\
\hline $\begin{array}{l}\text { DNA G + C content } \\
(\mathrm{mol} \%)\end{array}$ & 60 & 61 & 61 & 61 & 60 & 60 & 60 \\
\hline
\end{tabular}

clarify their iron-reducing activity, each strain was cultivated under anaerobic conditions, using lactate as an electron donor and carbon source and iron(III) oxyhydroxide or iron(III) citrate as an electron acceptor (Lovley \& Phillips, 1986). The amount of iron(II) in each culture bottle was measured by using ferrozine (Kostka \& Nealson, 1998). In comparison with F. balearica DSM $9799^{\mathrm{T}}$, the iron-reducing activity of strain $\mathrm{A} 4 \mathrm{D}-4^{\mathrm{T}}$ was too low to be detected by the ferrozine method.

Physiological and biochemical tests were performed by using the GN2 MicroPlate (BiOLOG) and APIZYME (bioMérieux) systems. Observation of utilization tests was continued for 1 week. Other tests, including those for casein hydrolysis, aesculin hydrolysis and production of indole, DNase, gelatinase, catalase, oxygenase, urease and amylase, were conducted as described by Smibert \& Krieg (1994). $\mathrm{H}_{2} \mathrm{~S}$ production was observed with SIM medium and TSI agar (Eiken). Based on the phenotypic characteristics, seven isolates could be differentiated into the two groups as shown in Table 2. The phenotype profile of the group incorporating strains A2A-18 and A3B-47-3 was similar to that of $F$. balearica DSM $9799^{\mathrm{T}}$. The group incorporating strains A2A$30, \mathrm{~A} 3 \mathrm{~B}-8, \mathrm{~A} 3 \mathrm{~B}-59$ and A4D $-4^{\mathrm{T}}$ could be classified as novel based on growth at $42^{\circ} \mathrm{C}, \mathrm{NaCl}$ requirement for growth, $\mathrm{H}_{2} \mathrm{~S}$ production on TSI agar, hydrolysis of casein, hydrolysis of aesculin and BiOLOG profiles for dextrin and D-glucose utilization.

The genus Ferrimonas was first described by Rosselló-Mora et al. (1995). The existence of Ferrimonas-related marine bacteria was recognized as $0 \cdot 2-\mu \mathrm{m}$-filterable bacteria in sea-water samples (Haller et al., 2000); however, the genus currently comprises only one recognized species, F. balearica (Rosselló-Mora et al., 1995). We have been able to show here the genetic and phenotypic diversity of Ferrimonas strains cultivated by using MA at $\mathrm{pH} 11$.

\section{Description of Ferrimonas marina sp. nov.}

Ferrimonas marina (ma.ri'na. L. fem. adj. marina of, or belonging to, the sea, marine).

Cells are $1-3.5 \mu \mathrm{m}$ long, Gram-negative rods motile by means of polar flagella. Circular, opaque, beige colonies are formed after 2 days in $\mathrm{MB}$ at $25^{\circ} \mathrm{C}$. Facultatively anaerobic. Growth occurs at $15-37^{\circ} \mathrm{C}$, with an optimum at $25-30^{\circ} \mathrm{C}$. The $\mathrm{pH}$ range for growth is $6 \cdot 0-11 \cdot 0$, with an optimum at $\mathrm{pH} 7 \cdot 0-8 \cdot 0 . \mathrm{NaCl}$ is required for growth; growth occurs over a concentration range of $1 \cdot 5-3.5 \%$ $(\mathrm{w} / \mathrm{v})$ and is optimal at $3.0 \%$. The quinone system of strain A4D-4 ${ }^{\mathrm{T}}$ grown in $\mathrm{MB}$ consists of MK-7 $(52 \cdot 2 \%)$, Q-7 $(25 \cdot 3 \%)$ and Q-8 (17\%). The fatty acid profile of strain $\mathrm{A} 4 \mathrm{D}-4^{\mathrm{T}}$ grown in $\mathrm{MB}$ includes iso- $\mathrm{C}_{15: 0}(11 \cdot 5 \%), \mathrm{C}_{16: 0}$ $(13 \cdot 9 \%)$ and $\mathrm{C}_{18: 1} \omega 9 c(16 \cdot 3 \%)$ as major components. Acid is produced from dextrin, D-glucose and maltose, but not from sucrose, D-fructose, D-mannitol, D-mannose, Dsorbitol, glycerol, lactose, L-arabinose or $m$-inositol. The $\mathrm{G}+\mathrm{C}$ content of the DNA is $60-61 \mathrm{~mol} \%$.

The type strain, A4D $-4^{\mathrm{T}}\left(=\mathrm{MBIC} 06480^{\mathrm{T}}=\mathrm{DSM} 16917^{\mathrm{T}}\right)$, was isolated from a macroalgal sample from Okinawa, Japan.

\section{Acknowledgements}

We thank Professor Patricia R. Bergquist at the University of Auckland, New Zealand, for identification of marine sponges. We thank Ayako Matsuzaki, Nakako Kinoshita, Tomomi Haga, Yukiko Itazawa and Midori Nozawa for their outstanding technical assistance. This work was supported by New Energy and Industrial Technology Development Organization (NEDO).

\section{References}

Altschul, S. F., Gish, W., Miller, W., Myers, E. W. \& Lipman, D. J. (1990). Basic local alignment search tool. J Mol Biol 215, 403-410.

Andersson, B. A. \& Holman, R. T. (1974). Pyrrolidides for mass spectrometric determination of the position of the double bond in monounsaturated fatty acids. Lipids 9, 185-190.

Cole, J. R., Chai, B., Marsh, T. L. \& 8 other authors (2003). The Ribosomal Database Project (RDP-II): previewing a new autoaligner 
that allows regular updates and the new prokaryotic taxonomy. Nucleic Acids Res 31, 442-443.

Ezaki, T., Hashimoto, Y. \& Yabuuchi, E. (1989). Fluorometric deoxyribonucleic acid-deoxyribonucleic acid hybridization in microdilution wells as an alternative to membrane filter hybridization in which radioisotopes are used to determine genetic relatedness among bacterial strains. Int J Syst Bacteriol 39, 224-229.

Haller, C. M., Rölleke, S., Vybiral, D., Witte, A. \& Velimirov, B. (2000). Investigation of $0 \cdot 2$-micron-filterable bacteria from the Western Mediterranean Sea using a molecular approach: dominance of potential starvation forms. FEMS Microbiol Ecol 31, 153-161.

Kostka, J. E. \& Nealson, K. H. (1998). Isolation, cultivation, and characterization of iron- and manganese-reducing bacteria. In Techniques in Microbial Ecology, pp. 58-78. Edited by R. S. Burlage, R. Atlas, D. Stahl, G. Geesey \& G. Sayler. New York: Oxford University Press.

Kumar, S., Tamura, K., Jakobsen, I. B. \& Nei, M. (2001). MEGA2: Molecular Evolutionary Genetics Analysis Software. Tempe, AZ: Arizona State University.

Lovley, D. R. \& Phillips, E. J. (1986). Organic matter mineralization with reduction of ferric iron in anaerobic sediments. Appl Environ Microbiol 51, 683-689.

Murray, R. G. E., Doetsch, R. N. \& Robinow, C. F. (1994). Determinative and cytological light microscopy. In Methods for General and Molecular Bacteriology, pp. 21-41. Edited by P. Gerhardt, R. G. E. Murray, W. A. Wood \& N. R. Krieg. Washington, DC: American Society for Microbiology.

Nishijima, M., Araki-Sakai, M. \& Sano, H. (1997). Identification of isoprenoid quinones by frit-FAB liquid chromatographymass spectrometry for the chemotaxonomy of microorganisms. J Microbiol Methods 28, 113-122.

Rosselló-Mora, R. A., Ludwig, W., Kämpfer, P., Amann, R. \& Schleifer, K.-H. (1995). Ferrimonas balearica gen. nov., spec. nov., a new marine facultative $\mathrm{Fe}(\mathrm{III})$-reducing bacterium. Syst Appl Microbiol 18, 196-202.

Sakane, T. \& Kuroshima, K. (1997). Viabilities of dried cultures of various bacteria after preservation for 20 years and their production by the accelerated storage test. Microbiol Cult Collect $13,1-7$.

Satomi, M., Oikawa, H. \& Yano, Y. (2003). Shewanella mariniintestina sp. nov., Shewanella schlegeliana sp. nov. and Shewanella saire sp. nov., novel eicosapentaenoic-acid-producing marine bacteria isolated from sea-animal intestines. Int J Syst Evol Microbiol 53, 491-499.

Smibert, R. M. \& Krieg, N. R. (1994). Phenotypic characterization. In Methods for General and Molecular Bacteriology, pp. 607-654. Edited by P. Gerhardt, R. G. E. Murray, W. A. Wood \& N. R. Krieg. Washington, DC: American Society for Microbiology.

Tamaoka, J. \& Komagata, K. (1984). Determination of DNA base composition by reversed-phase high-performance liquid chromatography. FEMS Microbiol Lett 25, 125-128.

Thompson, J. D., Gibson, T. J., Plewniak, F., Jeanmougin, F. \& Higgins, D. G. (1997). The CLUSTAL X windows interface: flexible strategies for multiple sequence alignment aided by quality analysis tools. Nucleic Acids Res 25, 4876-4882.

Van de Peer, Y. \& De Wachter, R. (1994). TREECON for Windows: a software package for the construction and drawing of evolutionary trees for the Microsoft Windows environment. Comput Appl Biosci 10, 569-570.

Weisburg, W. G., Barns, S. M., Pelletier, D. A. \& Lane, D. J. (1991). $16 \mathrm{~S}$ ribosomal DNA amplification for phylogenetic study. J Bacteriol 173, 697-703.

Yamamoto, S. \& Harayama, S. (1995). PCR amplification and direct sequencing of $g y r B$ genes with universal primers and their application to the detection and taxonomic analysis of Pseudomonas putida strains. Appl Environ Microbiol 61, 1104-1109. 